\title{
ФОРМУВАННЯ ФАХОВОЇ КОМПЕТЕНТНОСТІ МАЙБУТНІХ ІНЖЕНЕРІВ-ПЕДАГОГІВ У ПРОЦЕСІ ВИВЧЕННЯ ПРОФЕСІЙНО ЗОРІЕНТОВАНИХ ДИСЦИПЛІН
}

Філімонова I. А. Формування фахової компетентності майбутніх інженерівпедагогів у процесі вивчення професійно зорієнтованих дисциплін.

Сучасне харчове виробництво вимагає не лише високого рівня освіти та професійної майстерності майбутніх фахівців, а й готовності до інноваційної діяльності та до постійного самовдосконалення. Одним із ефективних напрямів модернізації освіти у професійній педагогіці визнано компетентнісний підхід, метою якого $є$ формування в майбутнього інженера-педагога фахової компетентності та формування відповідних компетенцій.

Ключові слова: харчове виробництво, фахова компетентність, інженер-педагог, професійна діяльність, ключові компетенції.

Филимонова И. А. Формирование профессиональной компетентности будущих инженеров-педагогов в процессе изучения профессионально-ориентированных дисциплин.

Современное пищевое производство требует не только высокого уровня образования и профессионального мастерства будущих специалистов, а также готовности к инновационной деятельности и постоянному самосовершенствованию. Одним из эффективных направлений модернизации образования в профессиональной педагогике признанный компетентностный подход, целью которого является формирование у будущего инженера-педагога специальной компетентности и формирование соответственных компетенций.

Ключевые слова: пищевое производство, профессиональная компетентность, инженер-педагог, профессиональная деятельность, ключевые компетенции.

Filimonova I. A. Forming professional competence of future engineers-teachers is in the process of learning the professionally-oriented disciplines.

Modern food production requires not only a high level of education and skills of professionals, but also commitment to innovation and to continuous improvement. One of the effective areas of modernization of education in vocational pedagogy is recognized competency based approach, which aims at developing in the future engineer-teacher professional competence and the formation of appropriate skills.

Key words: food production, professional competence, engineer, teacher, professional activity, core competencies.

Поглиблення нових ринкових відносин в економічному житті країни вимагає формування нових знань, засвоєння економічних механізмів регулювання ринків, адекватних новим умовам ринкових трансформацій та інтеграції у світовий ринок. Для того щоб задовольнити попит на ринку праці відповідними фахівцями, необхідно створити оптимальні організаційно-педагогічні умови для модернізації та подальшого розвитку системи професійної освіти. Одним із ефективних напрямів модернізації освіти у професійній педагогіці науковцями визнаний компетентнісний підхід, метою якого є формування в майбутнього працівника фахової компетентності, а основою - 
формування відповідних компетенцій [4, с. 49].

Нині наявна значна кількість науково-теоретичних і науково-методичних робіт, у яких аналізується сутність компетентнісного підходу (О. Овчарук, О. Пометун, Г. Терещук, А. Хуторський та ін.); проблеми формування ключових компетенцій (В. Байденко, М. Бочарнікова, В. Щербакова та ін.). Проте, незважаючи на збільшення кількості наукових публікацій $з$ проблем компетентнісного підходу, понятійний апарат, що характеризує сутність цього підходу в освіті, ще недостатньо обгрунтований. Немає науково-методичних розробок, що стосуються особливостей формування фахової компетентності випускників ВНЗ, викладачі яких не завжди уявляють, як можна реалізовувати компетентнісний підхід у навчанні.

Наразі виникла суперечність між вимогами стратегії модернізації освіти шляхом застосування компетентнісного підходу до процесу і результатів навчання та неопрацьованістю його методології, теорії і практики в освітньому процесі ВН3; між необхідністю використання компетентнісного підходу і недостатньою обізнаністю викладачів із методологією та методикою його впровадження. Крім того, історіографія проблеми свідчить, що формування фахової компетентності інженерапедагога в галузі харчової промисловості ще не було предметом спеціального дослідження [3, с.37].

Отже, зміна характеру й змісту праці фахівців галузі харчового виробництва та підвищення вимог роботодавців до рівня фахової компетентності працівників, що диктують необхідність упровадження компетентнісного підходу в підготовці майбутніх інженерів-педагогів, і недостатня опрацьованість методології, теорії i практики впровадження компетентнісного підходу в освітній процес коледжів, відсутність спеціальних досліджень проблем формування фахової компетентності інженера-педагога зумовлюють актуальність i доцільність теми дослідження «Формування фахової компетентності майбутніх інженерів-педагогів у процесі вивчення професійно зорієнтованих дисциплін».

Mema cmammi полягає у виявленні особливостей формування фахової компетентності майбутніх інженерів-педагогів сфери харчування.

Компетентнісний підхід як досягнення західної педагогічної думки заполонив нинішній вітчизняний освітній простір. Зазначимо, що цей підхід - освітня відповідь на актуальні потреби сучасного суспільства, особливо ринку праці. Така відповідь пов'язувалась 3 набуттям особистістю необхідних життєвих компетентностей. Це сутнісне обмеження - необхідність - у педагогічному варіанті представлено поняттям «ключові життєві компетентності».

Тлумачення поняття «компетентність» досить широке: до нього відносять і навчальні здібності, знання та вміння (вміння успішно навчатися) і навички (комунікативні, соціальні), і моральні цінності (громадянська відповідальність чи відповідальність за навколишнє середовище), і ставлення (групова солідарність). Відтак за структурою вирізняють організаційну, технологічну, екологічну, правову, політичну, культурологічну, соціальну, економічну компетентність, а також компетентність у сфері комунікативної діяльності та у сфері особистого повсякденного життя людини [6, с. 66].

Аналіз теорії та практики впровадження компетентнісного підходу показав, що він не лише змінює результативно-цільову основу професійної освіти, а й змінює сам тип навчання 3 іншими критеріями і процедурами, змістом, формами, методами, засобами, організацією відповідного освітнього середовища та діяльності в ній викладачів і студентів. 
Нині виокремлюють такі критерії фахової компетентності інженерів-педагогів: мотиваційно-ціннісний, змістово-когнітивний, операційно-діяльнісний, особистіснокорпоративний.

Діяльнісний підхід близький до ідеї компетентнісного підходу в межах тих компетентностей, які забезпечуються навчальними знаннями. Тут йдеться не про емпіричний їх рівень, а про рівень теоретичний, коли те чи те знання утримує внутрішні відношення, зв'язки, закономірності, властиві певному об'єкту чи явища. Відтак теоретичне знання пов'язується передовсім з узагальненим способом діяльності, а не 3 словесною оболонкою, з конкретним найменуванням речі. Тож теоретичне знання - це не що інше, як самостійне оперування предметом, уміння сконструювати його, розбиратися в ньому, використовувати його. Однак такі предметні дії і $є$ мисленням. Воно є здатністю обходитись 3 кожним предметом розумно, тобто відповідно до його власної природи.

Фахова компетентність інженера-педагога - не лише сукупність професійних знань, умінь і володіння способами виконання професійної діяльності, а також його професійно важливі якості, здібності, що впливають на ефективність професійної діяльності та успішність іiі освоєння; професійно значущі психофізіологічні властивості, необхідні для професійної діяльності [1, с. 45].

До особливостей професійної діяльності інженерів-педагогів у галузі харчового виробництва відносимо те, що сучасне харчове виробництво вимагає не лише високого рівня освіти, знань, культури, професійної майстерності, а й навичок i технологічної готовності до ухвалення рішень і дій у нестандартних умовах; творчого, ініціативного підходу до справи; вміння взяти на себе відповідальність за прийняті рішення; здатності до роботи в команді; готовність до інноваційної діяльності та до постійного самовдосконалення тощо.

Такий підхід дозволив у структурі фахової компетентності інженерів-педагогів виокремити етично-поведінковий, соціальний, мотиваційний, когнітивний i процесуальний компоненти. На формування відповідних цим компонентам компетенцій (загальнокультурних, соціально-психологічних, загальнопрофесійних i спеціальних) і було спрямоване вивчення професійно зорієнтованих дисциплін.

Загальнокультурні компетенції визначають готовність і прагнення ефективно взаємодіяти 3 іншими, розуміти себе та інших при постійній видозміні психічних станів, міжособистісних відносин і умов соціального середовища. Соціальнопсихологічні компетенції містять соціальні i психологічні компетенції, що забезпечують продуктивність безпосередньої трудової діяльності фахівця. До складу загальнопрофесійних компетенцій входять компетенції у сфері навчальної, науководослідницької, проектно-конструкторської, адміністративно-управлінської та виробничої діяльності. Спеціальні компетенції- ті, що необхідні для виконання певної професійної діяльності. Їх зміст визначається кваліфікаційними характеристиками.

3 урахуванням специфіки професійної діяльності інженера-педагога, структури його фахової компетентності та особливостей упровадження компетентнісного підходу у ВНЗ виокремлюють такі організаційно-педагогічні умови:

1) поєднання компетентнісного та особистісно-діяльнісного підходів під час вивчення професійно зорієнтованих дисциплін на основі використання інноваційних технологій навчання;

2) урахування у змісті професійно зорієнтованих дисциплін вимог роботодавця та забезпечення професійної мобільності, яка передбачає, що зміст професійної підготовки має вдосконалюватись і адаптуватись з урахуванням інновацій у техніці, 
технологіях виробництва, організації праці; виховання психологічної стійкості, готовності до конкурентної боротьби за робоче місце;

3) інтеграція знань 3 дисциплін циклів математичної, природничо-наукової та професійно-практичної підготовки за допомогою інтегрованих лекцій, бінарних занять, розв'язування професійних завдань, виконання інтегрованих завдань [5, с. 68].

Отже, компетентнісний підхід, у нашому розумінні, повинен забезпечити несуперечливу трансформацію суб'єкта учіння в суб'єкта розвиненої суспільної практики, точніше в суб'єкта практичної діяльності як цілеспрямованого перетворення дійсності. Йдеться про перетворення у формі і суб'єкт-об'єктній (виробничій), і в суб'єкт-суб'єктній (у формі міжлюдських відносин).

Наголосимо, що практика (як доцільна діяльність) постає цілісною системою дій. Ïї структура містить такі компоненти, як потреба, мета, мотив, предмет, на який спрямована ця діяльність, засоби, за допомогою яких досягається мета, і результат діяльності. Ці компоненти можуть перетворюватися один в одного, у цих перетвореннях і полягає iї динаміка. Конституюючою характеристикою практичної діяльності виявляється іiі предметність. Розвиток іiі предметного змісту визначає розвиток психічного відображення (образів). При цьому предметністю володіють не тільки пізнавальні процеси, але й уся сфера потреб, мотивів і емоцій [2, с. 31].

Сучасне суспільне життя висуває вимоги до особистості, яка повинна мати такі характеристики: мобільність, адаптивність, спроможність навчатися впродовж життя, толерантність, критичне мислення й оволодіння інформаційно-комунікаційними технологіями, передбачає використання людиноцентристської освітньої моделі, що грунтується на компетентнісно-орієнтованому змісті професійної освіти.

У цьому контексті $є$ актуальною проблема набуття індивідуумом ключових компетенцій і фахових компетентностей у процесі професійної підготовки, метою якої в умовах переходу до ринкових відносин $є$ підготовка висококваліфікованих, конкурентоспроможних кадрів з високим рівнем професійних знань, умінь, навичок, що відповідають вимогам науково-технічного прогресу й ринковим відносинам в економіці, формування в них наукового світосприйняття, творчого мислення [5, с. 89].

Перспективи подальших досліджень полягають у виявленні особливостей формування фахової компетентності майбутніх інженерів-педагогів сфери харчування вищих освітньо-кваліфікаційних рівнів (спеціаліста та магістра), формування фахової компетентності майбутніх інженерів-педагогів засобами інформаційнокомунікаційних технологій, формування фахової компетентності майбутніх фахівців на основі інших теоретико-методологічних підходів.

\section{Література}

1. Бібік Н. М. Компетентнісний підхід: рефлексивний аналіз застосування / Н. М. Бібік // Компетентнісний підхід у сучасній освіті: світовий досвід та українські перспективи: Бібліотека 3 освітньої політики / під заг. ред. О. В. Овчарук. - К. : «К.І.С.», 2004. - С. 45-50. 2. Гаврищак Г. Р. Компетентність та ключові компетенції викладача ВНЗ / Матеріали регіонального науково-практичного семінару «Професійні компетенції та компетентності вчителя», (Тернопіль, 28-29 листопада 2006 р.).Тернопільський національний педагогічний університет імені Володимира Гнатюка, 2006. - С. 31-32. 3. Герлянд Т. Сучасні аспекти формування професійної компетентності майбутніх кваліфікованих робітників / Тетяна Герлянд // Педагогіка $\mathrm{i}$ психологія професійної освіти: Науково-методичний журнал. - 2010. - № 1-2. С. 37-43. 4. Кадемія М. Ю. Сучасні методи та інноваційні технології навчання / М. Ю. Кадемія // Професійно-технічна освіта. - 2004. - № 2. - С.49-51. 
4. Компетентнісний підхід у сучасній освіті: світовий досвід та українські перспективи : Бібліотека 3 освітньої політики / під заг. ред. О. В. Овчарук. - К. : «К.І.С.», 2004. - 112 с. 5. Пометун О. Компетентнісний підхід - найважливіший орієнтир розвитку сучасної освіти/ О. Пометун // Рідна школа. - 2005. - № 1. - С. 6569.

УДК: $378.1+37.01+371$

Чжжоу Цун

\section{ПРОБЛЕМА ДОСЛІДНИЦЬКИХ УМІНЬ У СТУДЕНТІВ ВИЩИХ ПЕДАГОГІЧНИХ НАВЧАЛЬНИХ ЗАКЛАДІВ}

Чжоу Цун. Проблема дослідницьких умінь у студентів вищих педагогічних навчальних закладів.

У статті подано аналіз процесу формування дослідницьких умінь у студентів вищих педагогічних навчальних закладів. 3'ясовано поняття «дослідницькі вміння» в науковій літературі.

Ключові слова: дослідницькі вміння, студенти, вищий навчальний заклад, педагог-дослідник.

Чжоу Цун. Проблема исследовательских умений у студентов высших педагогических учебных заведений.

В статье представлен анализ процесса формирования исследовательских умений у студентов высших педагогических учебных заведений. Раскрыто понятие «исследовательские умения» в научной литературе.

Ключевые слова: исследовательские умения, студенты, высшее учебное заведение, педагог-исследователь.

Chzhou Tsun. The problem of research abilities among the students of higher pedagogical educational establishments

The article presents the analysis of the formation of research skills among students of higher pedagogical educational institutions.

Key words: research skills, students, higher educational institution.

У сучасних соціально-економічних умовах становлення Української держави особливого значення набуває проблема професійної підготовки майбутніх педагогів, увага приділяється реформуванню освіти. Глибоке розуміння сутності педагогічних явищ і процесів, творчий погляд і розв'язання педагогічних завдань неможливі без оволодіння майбутніми педагогами вміннями й навичками дослідницької діяльності. Одним із важливих завдань підготовки студентів є формування творчої особистості, здатної досліджувати, застосовувати новітні досягнення науково-технічного прогресу, змінювати традиційні підходи до процесу навчання на більш ефективні; розвиток здібностей до самовдосконалення та саморегуляції засвоєння нових знань i підвищення ефективності навчання.

Необхідність забезпечення високого рівня наукової підготовки є характерною ознакою сьогодення в усіх сферах педагогічної діяльності. Для забезпечення безперешкодного виходу студентів на ринок праці слід постійно підвищувати його конкурентоспроможність. На нашу думку, цього можна досягти шляхом розвитку інтелектуальних здібностей студентів, спрямування їхніх зусиль на інноваційне 